\title{
APLIKASI DAN PERANCANGAN SISTEM INFORMASI PEMESANAN PADA UPI CONVENTION CENTER DENGAN MENGGUNAKAN BAHASA PEMROGRAMAN PHP DAN MYSQL
}

\author{
Syaiful Zuhri Harahap ${ }^{1)}$ \\ Dosen Sistem Informasi Fakultas Sains dan Teknologi, Universitas Labuhanbatu \\ e-mail: syaifulzuhriharahap@gmail.com \\ Muhammad Halmi Dar ${ }^{2}$ \\ Dosen Manajemen Informatika Fakultas Sains dan Teknologi, Universitas Labuhanbatu \\ e-mail: mhd.halmidar@gmail.com
}

\begin{abstract}
ABSTRAK
Pada teknologi informasi yang semakin cepat seperti saat ini perkembangan ilmu pengetahuan dan teknologi terus maju dengan pesatnya. Hal ini menuntut setip usaha menajual jasa atau barang harus berpikir lebih untuk dapat bersaing dalam merebut para konsumen, dengan layanan yang baik untuk dapat memenangkan persaingan pasar. Hal ini telah mendorong berbagai perubahan-perubahan yang selalu sesuai dengan teknologi informasi, perubahan-perubahan tersebut perlu dikaji dan dianalisa oleh perusahaanperusahaan supaya dapat menjalankan roda usahanya. Salah satunya pemanfaatan kemajuan teknologi komputer yang pada masa sekarang maupun yang masa akan datang sangat dibutuhkan, karena disadari bahwa komputer merupakan alat bantu dalam menyelesaikan pekerjaan manusia secara cepat dan akurat. Suatu pekerjaan yang memakan waktu berhari-hari atau pekerjaan yang berulang-ulang dengan jumlah yang cukup besar dan menyita waktu dan biaya, oleh komputer dapat dilaksanakan beberapa menit saja. Disamping itu komputer juga dapat menyimpan data, memperbaiki data dan mengambil informasi yang dibutuhkan, data atau informasi tersebut disimpan dalam bentuk file, adanya alat bantu komputer tersebut maka pemecahan masalah akan dapat diatasi.
\end{abstract}

Kata kunci : Aplikasi, Sistem Informasi, Pemesanan, UPI Convention Center, PHP, MySql

\section{ABSTRACT}

In the increasingly fast information technology as it is today the development of science and technology continues to advance rapidly. This requires every business selling goods or services must think more to be able to compete in seizing consumers, with good service to be able to win market competition. This has led to various changes that are always in accordance with information technology, these changes need to be reviewed and analyzed by companies so that they can run their business. One of them is the utilization of computer technology advances, which are now and in the future are very much needed, because it is realized that computers are a tool in completing human work quickly and accurately. A job that takes days or repetitive jobs with a large enough amount and takes up time and money, by the computer can be done in just a few minutes. Besides that the 
computer can also store data, improve data and retrieve the information needed, the data or information is stored in the form of files, the existence of these computer aids will solve the problem can be overcome.

Keywords: Application, Information System, Ordering, UPI Convention Center, PHP, MySql

\section{PENDAHULUAN}

Salah satunya pemanfaatan kemajuan teknologi komputer yang pada masa sekarang maupun yang masa akan datang sangat dibutuhkan, karena disadari bahwa komputer merupakan alat bantu dalam menyelesaikan pekerjaan manusia secara cepat dan akurat. Suatu pekerjaan yang memakan waktu berhari-hari atau pekerjaan yang berulang-ulang dengan jumlah yang cukup besar dan menyita waktu dan biaya, oleh komputer dapat dilaksanakan beberapa menit saja. Disamping itu komputer juga dapat menyimpan data, memperbaiki data dan mengambil informasi yang dibutuhkan, data atau informasi tersebut disimpan dalam bentuk file, adanya alat bantu komputer tersebut maka pemecahan masalah akan dapat diatasi.

\section{LANDASAN TEORI Pengertian Reservasi}

Reservasi atau pemesanan berasal dari kata pesan yang artinya adalah setiap pemberitahuan, kata, atau komunikasi baik lisan maupun tertulis, yang dikirimkan dari satu orang ke orang lain. Pesan menjadi inti dari setiap proses komunikasi yang terjalin.

\section{Konsep Dasar Sistem Informasi}

Pemesanan yaitu menyediakan atau mempersiapkan tempat sebelumnya. Sedangkan reservation yaitu pemesanan suatu tempat fasilitas. Sehingga sistem informasi reservasi merupakan suatu sistem yang mengelola data pemesanan fasilitas.

\section{Pengertian Sistem}

Menurut Prof. Dr. Jogiyanto HM, MBA, AKT. (2005, hal:34) manusia hidup di dunia penuh dengan sistem. Lihat di sekeliling anda, maka apa yang anda lihat merupakan sekumpulan dari sistem-sistem yang sedang berjalan. Demikian juga dengan sistem informasi yang juga merupakan suatu sistem. Oleh karena itu, pemahaman suatu sistem terlebih dahulu akan membantu dalam pemahaman sistem informasi. Defenisi sistem dapat didefinisikan dengan yaitu pendekatan prosedur dan pendekatan komponen atau elemen. Dengan pendekatan prosedur, sistem dapat didefenisikan sebagai suatu jaringan kerja dari prosedur yang saling berhubungan untuk mencapai tujuan tertentu dan lebih menekankan urutanurutan operasi di dalam sistem. Dengan pendekatan komponen, sistem dapat didefenisikan sebagaikumpulan dari komponen yang saling berhubungan satu dengan yang lainnya membentuk satu kesatuan untuk mencapai tujuan tertentu. Pendekatan komponen lebih menekankan pada elemen atau kompenen dalam sistem

\section{METODE PENELITIAN}

Dalam melakukan penelitian ini, penulis mempergunakan tiga macam metodologi penelitian, antara lain:

\section{Penelitian Lapangan (Field Research)}

Pada bagaian ini saya melakukan penelitin secara langsung ke UPI CC, untuk mendapatkan data-data yang dirasa perlu dalam pembuatan website pemesanan secara online. Wawancara dilakukan 
secara langsung dengan asisten UPI CC yaitu Bapak Yuniardi

\section{Penelitian Perpustakaan (Library Research)}

Mengumpulkan teori yang berkenaan dengan pembuatan sistem informasi pemesanan UPI CC dengan membaca buku-buku , jurnal, artikel dari internet tentang pemesanan.

\section{Penelitian Laboratorium (Laboratory Research)}

Dengan adanya data yang diperoleh, kemudian penulis mencoba mempraktekannya dengan komputer dengan menggunakan bahasa pemrograman PHP.

\section{HASIL DAN PEMBAHASAN}

Analisa sistem adalah menganalisa suatu sistem informasi yang utuh kedalam beberapa bagian-bagian untuk dievaluasi permasalahan-permasalahan, permsalahanpermasahan yang terjadi dalam sistem dan kebutuhan-kebutuhan yang diharapkan sehingga dapat diusulkan perbaikan.

Suatu sistem pada dasarnya merupakan suatu susunan teratur dari sekumpulan kegiatan-kegiatan yang saling berhubungan antara satu dengan yang lainnya, dan prosedur-prosedur yang dilaksanakan saling berkaitan sehingga kemudahan untuk melakukan kegiatan. Perkembangan suatu sistem sering kali dipengaruhi oleh perubahan kondisi yang dihadapi.

\section{Pengujian Sistem}

Pengujian sistem dilakukan untuk menggambarkan sebuah sistem yang berjalan. Tahapan ini berisikan hasil eksekusi program dan penjelasan program yang dibuat untuk mendukung sistem yang telah dirancang.

\section{Tampilan Home Admin Form Login Admin}

Form login Admin berfunsi untuk masuk ke dalam sistem, yakni dengan cara mengisikan user name, lever dan password yang tertera pada form login Admin tersebut dan memilih level Admin. Berikut adalah tampilan form login Admin yang terlihat pada Gambar 1 berikut ini:

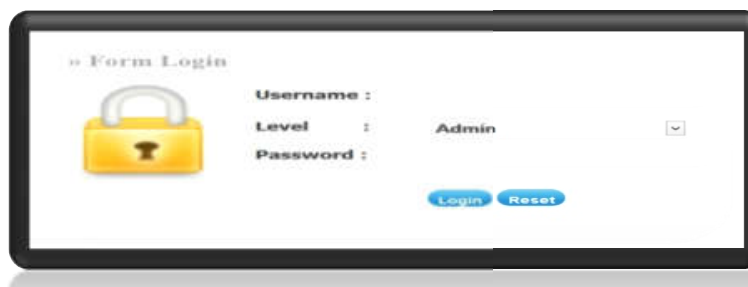

Gambar. 1 Halaman Login Admin Form Menu Utama Admin

Form admin terdiri dari beberapa menu. Menu-menu pada form admin ini berfungsi agar admin dapat mengedit, entry data, hapus data, serta admin juga bisa untuk menambahkan data Barang. Menu-menu yang ter dapat pada form admin antara lain home, manajemenu user, manajemen produk, manajemen customer, halaman, log out. Berikut adalah tampilan halaman admin yang terlihat pada gambar 2 berikut ini:

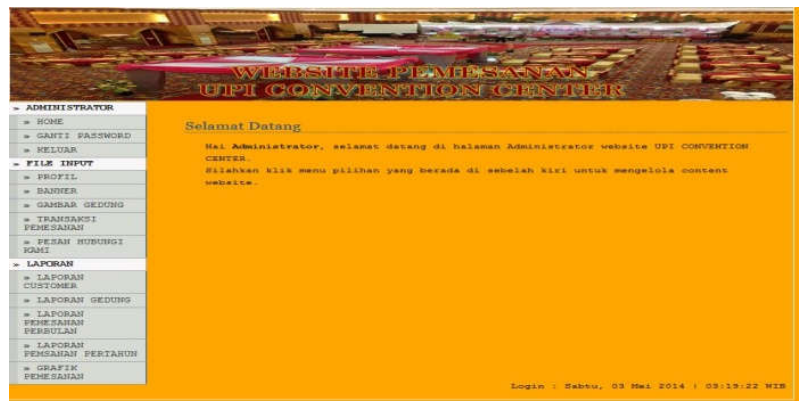

Gambar 2Menu Utama Admin

\section{KESIMPULAN DAN SARAN}

Rancangan sistem informasi yang baru mudah-mudah memberikan kemudahan dalam melakukan pemesanan secara online oleh customer, pengolahan data dan penyajian informasi, nantinya akan dapat 
membantu UPI Convention Center dalam sistem efesiensi efektifitas pemesanan yang lebih baik sesuai dengan perkembangan teknologi informasi.

Adapun kesimpulan yang dapat diambil dari pembahasan skripsi ini adalah:

Aplikasi website ini dapat memudahkan UPI Convention Center Padang dalam melakukan pemesanan gedung kepada pelanggan(customer). Yang selama ini hanya melalui pemesanan secara langsung datang ke UPI Convention Center

Berdasarkan website yang dirancang dapat mempermudah pihak UPI Convention Center padang dalam mengupdate data produk, customer, pemesanan dan promosi dengan menggunakan website ini.

Daftar Pustaka disajikan mengikuti tata cara seperti contoh berikut, disusun secara alfabetis dan kronologis.

\section{DAFTAR PUSTAKA}

Jogiyanto. 2005.Analisa dan desain. Yogyakarta:Andi.

Basuki,Achmad. Graphic User Interface (GUI). E-book.

Munawar. 2005. Permodelan Visual dengan UML. Yogyakarta : Graha Ilmu.

Jogiyanto. 2008. Sistem Teknologi Informasi Edisi III. Yogyakata: Andi

Kadir, Abdul. 2010. Mudah Mempelajari Database MYSQL. Yogyakarta: Andi.

Hartono, Jogiyanto, M.B.A,Ph.D. 2000. "Pengenalan Komputer edisi ketiga cetakan Kedua”. ANDI, Yogyakarta.
Heryanto, Imam. \& Raharjo, Budi .2007. "Mudah Belajar PHP” Bandung. Informatika.

Jogiyanto H.M .2005 . "Analisa dan Disain Sistem Informasi”. Yogyakarta. Andi Offset,

Jogiyanto H.M. 2005. Sistem Teknologi

Informasi. Yogyakarta : Andi Offset

Kadir, Abdul. 2010, "Mudah Mempelajari Database MySQL". Yogyakarta : Penerbit Andi

Nugroho, Adi. 2011, "Perancangan dan Implementasi Sistem Basis Data". Yogyakarta : Penerbit Andi

Sariadin Siallagan. 2009, Pemograman PHP Dasar-dasar Pengenalan \& Pemahaman, Yogyakarta : Andi Offset

Witarto. 2005. Memahami Sistem Informasi. Bandung : Informatika 